Scientia Militaria vol 40, no 3, 2012, pp.222-249. doi: 10.5787/40-3-1043

\title{
The South African Air Force, 1920-2012: A Review of its History and an Indication of its Cultural Heritage
}

André Wessels •

\begin{abstract}
Although a South African Aviation Corps existed for a few months in 1915, and although several South Africans saw action in World War I as members of Britain's Royal Flying Corps, the history of the South African Air Force (SAAF) - the world's second oldest air force - strictly speaking only dates back to 1 February 1920. In this article, a review is provided of the history of the SAAF, with specific reference to its operational deployments in the 1920s; the difficult years of the great depression and its aftermath and impact on the SAAF; the very important role played by the SAAF in the course of World War II (for example in patrolling South Africa's coastal waters, and in taking part in the campaigns in East Africa and Abyssinia, as well as in North Africa, Madagascar, Italy, over the Mediterranean and in the Balkans); the post-war rationalisation; its small but important role in the Korean War; the acquisition of a large number of modern aircraft and helicopters from the mid-1950s to the mid-1970s; the impact that sanctions had on the SAAF; the SAAF's role in Northern Namibia and in Angola
\end{abstract}

Department of History, University of the Free State. Also a visiting fellow, University of New South Wales at the Australian Defence Force Academy (UNSW@ADFA), Canberra. The sources that were used in writing this article are freely available. See, for example, in general www.af.mil.za, www.saafa.co.za and www.saairforce.co.za. The general research assistance provided by Marilie Brink and Annél Oosthuysen is gratefully acknowledged. The assistance provided by Warrant Officer Alan Taylor (SAAF Museum, AFB Swartkop) with regard to identifying where ex-SAAF aircraft can still be seen today is also gratefully acknowledged. See in this regard also W Brent (compiler). 85 years of South African Air Force 1920-2005. Nelspruit: Freeworld, 2005. 
during the war years, 1966-1989, and the SAAF in post-apartheid South Africa. Throughout the article, historiographical matters are mentioned by means of references - either in the text or in footnotes - to the most important available sources.

Keywords: South African Air Force, Second World War, Korean War, Border War, South African air force museums, aviation/cultural heritage

\section{Introduction}

At the South African Air Force (SAAF) Museum at Air Force Base (AFB) Swartkop, Pretoria, as well as at several other museums in South Africa and at other SAAF bases, several decommissioned aircraft and helicopters of the SAAF are on display. These artefacts remind the visitor of the fascinating history of the SAAF. Proceeding from the assumption that it is imperative for any country to have a well-balanced air force, it is the purpose of this article to provide a review of the history of the SAAF from 1920 to the present day (2012). Throughout, the emphasis will fall mainly on operational and other developments, rather than on structural, personnel and administrative matters. The cultural history aspect will be limited to SAAF aircraft and helicopters per se. Historiographical matters will be addressed by referring to some of the books and articles that have thus far been written on the history of the SAAF. In most cases, the authors of these works are so-called "amateur" historians and aviation enthusiasts - an indication that much serious scholarly work still needs to be done in this regard. For obvious reasons, this article merely comprises a broad introduction to a wide-ranging topic; it therefore needs to be read against the background of the hundredth anniversary of South Africa's armed forces. Indications as to where examples of some of the older aircraft and helicopters are on display, will be provided throughout. These aircraft and helicopters form part of the SAAF's, but also South Africa's, aviation and cultural heritage.

When the Union Defence Forces (UDF) were established on 1 July 1912, less than a decade had elapsed since Wilbur and Orville Wright had flown the first aircraft at Kitty Hawk in the United States of America (USA) on 17 December 1903. The South African Defence Act of 1912 provided for the establishment of a South African Aviation Corps (SAAC) as part of the Active Citizen Force (ACF). In August 1912, the commandant general 
of the ACF, Brig. Gen. C.F. Beyers (one of the famous Boer guerrilla commanders during the Anglo-Boer War, 1899-1902), went to Europe to attend military manoeuvres as an observer. He was impressed by the potential of aircraft in terms of their possible use by the military, and was instrumental in recruiting men to be trained as pilots. Ten men, out of hundreds who applied, were selected to undergo training by the Paterson Aviation Syndicate (Ltd) near Kimberley. Of these, five were later sent to England for advanced training, and when the Great (First World) War broke out in 1914, they joined Britain's Royal Flying Corps (RFC). Back in the Union of South Africa, the SAAC was formally established as part of the ACF on 29 January 1915. During the campaign in German South West Africa (today Namibia), the SAAC successfully flew Henri Farman F27 aircraft in a reconnaissance role. ${ }^{1}$

At the end of the campaign, the SAAC was disbanded and its members were allowed to join the RFC as volunteers. In Britain, they formed the nucleus of 26 South African Squadron (RFC). At the beginning of 1916, the squadron arrived in German East Africa (today Tanzania), where they carried out reconnaissance work, liaison work and air attacks in support of Gen. J.C. Smuts's ground forces. The squadron returned to Britain in June 1918 and was disbanded the following month. Other South Africans served in various other RFC squadrons, including Capt. A.F.W. Beauchamp Proctor, who shot down 38 German aircraft and 16 balloons, and who was awarded the Victoria Cross. ${ }^{2}$

\section{A Fledgling SAAF, 1920-1939}

After Britain's Royal Air Force (RAF), the South African Air Force (SAAF) is the oldest air force in the world. Gen. J.C. Smuts was determined that the UDF should also acquire its own air force. Col H.A. van Ryneveld was appointed as Director of Air Services. His appointment in this capacity was back-dated to 1 February 1920, and this date marks the birth of the SAAF, albeit that the Air Force was only officially listed as a unit of the reorganised UDF on 1 February 1923. Already in 1919, the British government decided to give the UDF an "imperial gift" of no fewer than 100 aircraft: 48 De Havilland D.H.9s, 30 Avro 504Ks and 22 S.E.5a Scouts. Thirteen aircraft were also received from other sources, namely ten D.H.4s and one D.H.9 from the Overseas Club of London, and two Royal Aircraft 
Factory B.E.2Es left behind by Maj. Allister Miller, RFC, after a recruitment drive in 1916. (Some of the aircraft, for example the Avro 504s, were never used by the SAAF, but were sold to civilian buyers.) The SAAF's first airfield and base, which was situated at Zwartkop (today Swartkop) just outside Pretoria, was acquired in 1921. There, 1 Squadron was established in 1922. ${ }^{3}$ The only surviving examples of these aircraft are the single D.H.9 and the single S.E.5a, which can be seen at the Ditsong National Museum of Military History (previously known as the South African National Museum of Military History) at Saxonwold, Johannesburg.

The SAAF's first-ever operational deployment took place during the Rand strike (or revolt) of 1922, when 1 Squadron performed reconnaissance flights and also bombarded the strikers' positions. On the first day of operations (10 March), Capt. W.W. Carey Thomas was mortally wounded when his D.H.9 was hit by ground fire. On the same day, Col H.A. van Ryneveld had to make an emergency landing when his aircraft, too, was hit by ground fire. The SAAF flew a total of 127 hours during the strike, and lost two of its members who were killed, two were wounded, and two aircraft were irreparably damaged. From 29 May to 3 July 1922, the SAAF was also successfully deployed during the suppression of the Bondelswarts revolt in South West Africa (SWA). In 1925, the SAAF was once again in action in SWA, this time in the suppression of the revolt by the Rehoboth Basters. ${ }^{4}$

The post-Great War depression, as well as the great world depression (1929-1934), impacted on the SAAF's development, but the fledgling air force continued to expand nevertheless. A small aircraft industry was launched when stronger engines were locally installed in some of the D.H.4 and D.H.9 aircraft (1924-1928), and on 27 April 1931, the first (of 30) locally licence-built Westland Wapiti aircraft made its maiden flight. These aircraft were followed by 68 Hawker Hartbees (1936-1939) and 42 Avro Tutor aircraft (1935-1936). After the South African economy had recovered in 1934, the SAAF was expanded to seven squadrons, and new bases and flight schools were established at Waterkloof (outside Pretoria), Bloemfontein, Durban and Youngsfield (near Cape Town). In 1934, three D.H.66 Hercules transport planes were acquired by the SAAF, followed later by a single Gloster A.S.31 survey aircraft, as well as seven Hawker Furies. $^{5}$ With war clouds gathering once more in Europe, the SAAF 
acquired a number of aircraft from the RAF in 1938, namely Hawker Harts, Hawker Hinds and Audaxes. However, these were old aircraft. ${ }^{6}$ Notwithstanding efforts to expand the SAAF in the course of the 1930s, it was ill-prepared to conduct large-scale operations by the time the world was plunged into a new war in 1939.

\section{The SAAF in the Second World War, 1939-1945}

The history of the SAAF in World War II has been described and analysed in a series of books entitled South African Forces in World War II by, for example, J.A. Brown in A gathering of eagles: The campaigns of the South African Air Force in Italian East Africa June 1940-November 1941 with an introduction 1912-1939 (Cape Town: Purnell, 1970); J.A. Brown, Eagles strike: The campaigns of the South African Air Force in Egypt, Cyrenaica, Libya, Tunisia, Tripolitania and Madagascar 1941-1943 (Cape Town: Purnell, 1974) and H.J. Martin and N.D. Orpen, Eagles victorious: The South African Forces over the Mediterranean and Europe, in Italy, the Balkans and the Aegean, and from Gibraltar and West Africa (Cape Town: Purnell, 1977). For a World War II squadron history, see E.N. Tucker and P.M.J. McGregor, Per noctem per diem: The story of 24 Squadron, South African Air Force (s.l.: 24 Squadron Album Committee, 1961; reprinted 1962).

When war once again broke out in Europe on 1 September 1939, the SAAF had 173 permanent force officers, 35 cadet officers and 1664 officers of other ranks. The SAAF's aircraft inventory consisted of 104 aircraft. The only operational types were six Hurricane Mk Is, one Fairey Battle light bomber, and one Bristol Blenheim bomber. In addition, there were the 63 outdated Hawker Hartbeeste, as well as a number of Tutors, Wapitis, Hawks, Hinds, Envoys, Audaxes, and three D.H.66 Hercules and a single Gloster A.S.31. There were also some 250 civilian aircraft in the country, including the South African Airways' 11 Junkers Ju-52/3ms and 18 Ju-86s. These aircraft were taken over by the SAAF. The Ju-52/3ms were used as military transport planes, and the Ju-86s as bombers and maritime patrol aircraft. ${ }^{7}$ Several civilian airports were henceforth also used by the military, for example, Wingfield in Cape Town. ${ }^{8}$ 
Soon after the outbreak of hostilities, new flying schools were established in Pretoria, Germiston, Baragwanath and Bloemfontein. On 26 February 1940, a training command was established. That same year saw the establishment of the Joint Air Training Scheme (JATS), which provided for the training of SAAF, RAF and other allied air and ground crews at 38 air training schools in South Africa. This boosted the expansion of the SAAF, which by September 1941 had 31204 personnel, including 956 pilots, and there were a total of no fewer than 1709 aircraft in the country. In the course of the war, 33347 aircrew were trained under the JATS, including 7764 pilots. SAAF personnel comprised 12221 of the aircrew, while the rest were mainly RAF members. ${ }^{9}$

The SAAF's first war task was to safeguard South Africa's coast, in particular the Cape sea route. In the course of the war, approximately 15000 reconnaissance flights were undertaken along the coast, initially using converted Junkers Ju-86s, then Avro Ansons (one of which can today be seen at the SAAF Museum at AFB Swartkop), and later (from 1942 onwards) Venturas, supplemented by RAF and Royal Netherlands Air Force Catalina flying boats. The SAAF's Coastal Command aircraft attacked 26 submarines, intercepted 17 merchant ships, and rescued 437 seamen. ${ }^{10}$ To rescue crew members who had been obliged to ditch their aircraft at sea, the SAAF established an air-sea rescue service in 1939, and received its first crashboat (named Malmok) in 1940. In due course, 19 crashboats that had been built for the SAAF by the Miami Shipbuilding Corporation in Florida, USA, arrived: eight in 1941 and 11 in $1944 .{ }^{11}$ One of these Miami boats has survived until today (2012), and is used as a privately owned pleasure boat in Durban harbour - under the name Allen Gardiner.

In Abyssinia and Somalia, the Italians had 383 modern aircraft, while the SAAF initially had to rely on their few Hartbeeste, Furies, Gladiators, Hurricanes and Ju-86s - in total only about 40 aircraft. The SAAF provided much-needed air support to the ground forces, shot down a total of 71 Italian aircraft, destroyed many others on the ground, and attacked convoys, railways, and stores and other depots. Total SAAF losses in this campaign (which ended on 19 May 1941) amounted to 79 pilots killed and five missing. During this campaign, the SAAF carried out 6517 sorties, and also established a shuttle service between South Africa and the operational areas. Troops, as well as stores and other matériel, were transported from 
South Africa to the north, while wounded personnel were brought back to the Union for treatment. Initially, bombers were used for the purpose of transportation, but they were supplemented in due course by Dakota transport planes. As the war spread to other areas, the shuttle service also moved northwards - first to Egypt, and later to Italy. After the cessation of hostilities in Europe, the ideal was to bring back all South African troops before Christmas 1945. Although this target was not fully achieved, the SAAF had transported 101676 passengers by 25 January $1946 .{ }^{12}$

The SAAF continued its successes in North Africa and in the Western Desert. By as early as April 1941, the SAAF's aircraft had assisted the Allies' Desert Air Force to gain air supremacy in this war zone. The SAAF conducted reconnaissance flights, bombing and ground-attack missions, intercepted enemy aircraft, and pursued the Axis forces after the decisive battle at El Alamein (October 1942). From April 1941 to May 1943, the SAAF conducted 33991 sorties and destroyed 342 enemy aircraft in North Africa. ${ }^{13}$

In the meantime, the SAAF also took part in the Allied campaign to capture Madagascar (Operation Ironclad), albeit on a much smaller scale than was the case in other war zones. In the run-up to the Allied landings at Diego Suarez (May, 1942), SAAF Marylands undertook several photoreconnaissance flights. Marylands, Beauforts and Lodestars were later operationally deployed with RAF aircraft. By the time a cease-fire was proclaimed on 5 November 1942, the SAAF had engaged in 401 sorties, lost seven aircraft (only one in action), and had also lost three men: one pilot was killed in action, one died in an accident, and a third one died from disease. $^{14}$

After the war in North Africa ended, SAAF squadrons took part in the bombardment of Axis positions on the island of Sicily, prior to the Allied invasion, which commenced on 9 June 1943. By the time the Italian mainland campaign started on 3 September 1943, the SAAF had developed into a force to be reckoned with, and when RAF units were withdrawn from this war zone in support of the Allied D-Day landings (June 1944) in France, the SAAF was more than able to take on additional responsibilities. By September 1944, the SAAF had 17271 personnel in Italy, with 35 squadrons flying a total of 33 types of aircraft. This included the Spitfire 
Mk V fighter, Martin Marauder II and III bombers, as well as Mosquitos, Baltimores and Liberators. Today, a Mosquito aircraft is on display at the Ditsong National Museum of Military History, while a Spitfire is in storage at AFB Swartkops Museum. The SAAF operations in Italy only ended when Germany capitulated in May 1945. Since the end of the campaign in North Africa, the SAAF had flown no fewer than 82401 sorties. $^{15}$

SAAF aircraft and crew also saw service in other war zones. In the Mediterranean area, the SAAF conducted coastal reconnaissance and transport work. Targets on the Greek coast and islands, as well as in the Adriatic Sea, were attacked. ${ }^{16}$ Venturas flown by 22 Squadron operated from Gibraltar against German U-Boats, while 26 Squadron's Wellingtons operated from Takoradi in the Gold Coast (today Ghana). ${ }^{17}$ In the Balkans, the SAAF also saw action in collaboration with other allied forces, and they supported the partisans in Yugoslavia. ${ }^{18}$ In August-September 1944, 31 Squadron and 34 Squadron engaged in 181 sorties from bases in Italy to support the Polish resistance fighters who had staged an uprising in Warsaw. In the course of this operation, the SAAF lost 11 aircraft and 38 crew were killed. ${ }^{19}$

By the end of the war, 44569 men had served in the SAAF, the SAAF had carried out a total of approximately 140000 sorties, it had used approximately 5000 aircraft, 2319 SAAF personnel had died in active service, and 932 had been wounded or injured, while about 280 had been taken prisoner. ${ }^{20}$ Amongst the well-known South African pilots were Flight Lt M.T. St J ("Pat”) Pattle (with 41 kills to his credit and regarded as the best RAF and British Commonwealth pilot), Maj. Jack Frost (killed in air combat over the Western Desert, June 1942), Group Capt. A.G. ("Sailor") Malan (RAF), Wing Commander J.D. Nettleton (RAF), who received the Victoria Cross (VC) for a daring daylight raid on a German factory, and Capt. Edwin Swales (RAF), who received the VC posthumously. ${ }^{21}$

\section{The Post-War SAAF, 1945-1966}

In line with the other arms of the UDF, the SAAF was scaled down after the end of World War II. Many aircraft were also discarded, but a British government gift of 80 Spitfire Mk IXs was retained (and an additional 56 Spitfires were bought), while a gift of 12 Short Sunderland Gr.4 flying boats 
was also accepted and three additional Sunderlands were purchased. The SAAF retained their Douglas C47 Dakota transport planes, 106 of which were in service over the course of time, after the first ones were received by the SAAF in 1943 - and today (2012), at least ten of these venerable aircraft continue to serve in the SAAF, albeit that they have been rebuilt as the C47TP (also referred to as the Turbo Dak). ${ }^{22}$ On 16 November 1946, the SAAF also received a single Fieseler Fi 156 C-7 Storch rescue and liaison plane from the RAF. This plane had been captured from the German Luftwaffe. After having been stationed at the Central Flying School at Dunnottar, the aircraft was withdrawn from service on 28 October 1947. Thirty years later, it was restored to flying condition, and it is now kept by the SAAF Museum at AFB Swartkop. ${ }^{23}$

In 1948 - the year in which the National Party (NP), led by Dr D.F. Malan, came to power (with its policy of apartheid) - three Sikorsky S-51 helicopters were bought from the USA. The SAAF was keen to introduce the new helicopter technology into its inventory, albeit that in practice the helicopters were used for the non-military purpose of combating the tsetsefly plague in north-eastern (KwaZulu-Natal. ${ }^{24}$ The political changes in the country also meant that the country's defence forces, including the SAAF, underwent "cultural changes", for example, the NP tried hard (with a considerable degree of success) to rid the country's armed forces of their "British" character and to place more Afrikaans-speaking persons in top positions. Also in 1948, when the Soviet Union cut off the land supply lines between West Germany and the enclave of West Berlin, and the Western countries created an elaborate air bridge, the SAAF provided 20 air crews. After undergoing intensive training at the RAF base at Bassingbourne, the SAAF crews flew 1240 sorties in Dakota aircraft from Lübeck to West Berlin, and by the time the blockade was lifted in April 1949, the SAAF had flown in at least 4000 tons of supplies. ${ }^{25}$

When communist North Korea invaded pro-western South Korea on 25 June 1950, the South African government decided to send the personnel of 2 Squadron to assist the United Nations (UN) forces that were deployed to assist the South Koreans. The role of the SAAF in Korea has been described by, for example, D.M. Moore and P. Bagshawe in South Africa's flying cheetahs in Korea (Rivonia: Ashanti Publishing, 1991) and W. Brent in "Flying cheetahs": Korea 1950-1953 (Nelspruit: Freeworld Publications, 
s.a.). On 27 September 1950, 49 officers and 57 men of 2 Squadron left for Japan, from whence they proceeded to South Korea. All in all, 826 South Africans would eventually serve in Korea. There they flew F-51D Mustangs and later (as from January 1953) F-86F Sabres - as part of the United States Air Force's $18^{\text {th }}$ Fighter-Bomber Wing. (There is a Mustang at the SAAF Museum at AFB Swartkop, albeit not an ex-SAAF aircraft.) The SAAF's first operational sortie took place on 19 November 1950, at a time when the UN forces were falling back, and in bitterly cold weather. Osan in due course became 2 Squadron's main base, from whence they mainly conducted ground-attack and interdiction missions. The war in Korea ended on 29 July 1953, and by that time, 2 Squadron had engaged in 12067 sorties and lost 74 out of 97 Mustangs and five out of 22 Sabres, as well as 34 pilots and two ground crew members who had died. (In addition, nine had been taken prisoner. $)^{26}$

The SAAF did not take any aircraft to Korea or bring back any new ones - but the SAAF did undergo a metamorphosis in the 1950s and 1960s as far as its aircraft inventory is concerned. While the North American T-6 Harvard remained the SAAF's basic trainer from 1942 to 1995 (with a total of 735 having been used at some time or other), ${ }^{27}$ and trained many excellent pilots, the venerable Spitfires were withdrawn from service in 1954 and replaced by the SAAF's first jet aircraft, namely 77 De Havilland Vampires (1950-1956): ten F.B. Mk5s (1950), ten F.B. Mk6s (1951), six T. Mk11 trainers (1953), 30 F.B. Mk52s (1953) and 21 T. Mk 55 trainers (1954-1956). ${ }^{28}$ No. 218 was later displayed outside Air Force Station Voortrekkerhoogte. A Vampire F.B. Mk52 can be seen at the SAAF Museum at AFB Ysterplaat, while another Vampire is stationed at AFB Swartkop. In the light of the success achieved with Sabres by 2 Squadron in Korea, 34 Canadair CL-13B Sabre Mk6s were acquired by the SAAF in $1956 .{ }^{29}$ The Sunderlands were withdrawn from service in 1957 and the last Venturas (used as maritime patrol aircraft, MPA), in 1960. A Lockhead PV1 Ventura can be seen at the SAAF Museum at AFB Ysterplaat, and a Ventura used as VIP transport for Gen. J.C. Smuts is stationed at AFB Swartkop. The SAAF's new MPA were comprised of eight Avro Shackleton Mk2s, acquired in $1957 .{ }^{30}$ In 1956-1957, the SAAF acquired new helicopters, namely three Sikorsky S-55s. ${ }^{31}$ 
The SAAF bought a number of Auster AOP-6s for use in artillery control: five Auster AOP-6s in 1953 and two AOP-9s in 1957, as well as two small Dornier DO-27s in $1958 .^{32}$ A quantum leap ahead as far as sophistication is concerned was made with the arrival of the French-built Mirage III jets from April 1963 onwards: 16 Mirage IIICZ interceptors/fighters (1963), three two-seater Mirage IIIBZ conversion trainers (November 1964), 16 Mirage IIIEZ multi-role/strike/ground-attack aircraft (1965), four Mirage IIIRZ and four Mirage R2Z tactical reconnaissance aircraft (1967 and 1974), four Mirage IIIDZ trainers (1965) and 11 Mirage D2Z trainers (1974). ${ }^{33}$ Other aircraft acquired were six English Electric Canberra B(I)12 bombers and three Canberra T.Mk4 trainers from Britain (1963), ${ }^{34} 16$ Hawker Siddeley Buccaneer S. Mk50 maritime strike aircraft from Britain (1965) ${ }^{35}$ and seven Lockhead C-130B Hercules transport aircraft from the USA (1963), ${ }^{36}$ as well as 45 Cessna 185 Skywagon liaison/spotter aircraft (1962-1968), also from the USA. ${ }^{37}$

The SAAF also acquired large numbers of helicopters: eight Aerospatiale Alouette II (1960-1961) and 121 Alouette III (1962-1975) light helicopters from France, ${ }^{38}$ and 16 Westland Wasp HA5.Mk1 antisubmarine warfare helicopters from Britain (1963-1974), inter alia to be operated (by the SAAF) from the South African Navy's warships. ${ }^{39}$ For many years (as from 1958), the SAAF's VIP Squadron (No. 21) flew a single Vickers Viscount 781D (named Casteel), which was supplemented by four Hawker-Siddeley HS-125 jets in 1970 (further supplemented by three others in 1972, after three of the original aircraft crashed on 26 May 1971, killing all 11 persons on board), and seven Swearingen Merlin IVAs (June 1975-June 1976). ${ }^{40}$ In 1966, the SAAF also received eight Douglas DC-4 Skymaster passenger aircraft from the South African Airways. ${ }^{41}$ All these new aircraft and helicopters transformed the SAAF into a formidable force.

Other developments in the years 1951 to 1966 include the establishment of the SAAF Gymnasium on 1 December 1951 (since 1959 situated at Valhalla, just south of Pretoria), as well as the SAAF College (1951) and several radar stations. ${ }^{42}$ As opposition against the NP government grew and unrest broke out in black townships, the SAAF (especially its helicopters) were called upon from time to time to assist the South African Police (SAP) (and sometimes army units) in restoring law and 
order. But to the north of the RSA, developments were taking place that in due course would test the SAAF's abilities as never before.

\section{The War in Namibia and Later Also in Angola, 1966-1989 ${ }^{43}$}

In 1966, the SAAF had 36 Mirage III jets, 25 Sabres, seven Buccaneers, nine Canberras, some 70 Vampires, seven C-130s, eight Douglas DC-4 Skymasters, 80 Dakotas, some 300 Harvards, 34 Cessna 185s, seven Shackletons, seven Alouette IIs, some 50 Alouette IIIs, and nine Wasps. ${ }^{44}$ When the South West African People's Organisation (Swapo) launched its first incursion into SWA in 1966, the SAP was initially tasked to keep the peace, and the SADF only assumed responsibility for the defence of SWA in 1973. ${ }^{45}$ However, even before the end of 1966, a number of SAAF liaison officers were sent to Cuito Cuanavale in Angola (then still a Portuguese colony) to conduct operational planning in consultation with Portuguese officers, because the SADF was assisting the Portuguese authorities in efforts to intercept Swapo cadres before they could cross the border into SWA. The SAAF did, in fact, send Alouette III helicopters and Cessna 185 aircraft to northern SWA in order to assist the SAP. These aircraft were, for example, used for the purpose of photo reconnaissance work. But in July 1967, SAAF helicopters were used actively in combat operations against Swapo for the first time, and on 10 June 1968, 1 Air Component was established at Rundu, from whence cross-border operations were launched against Swapo (Operation Bombay). The SAAF also supported counterinsurgency operations in Rhodesia (present-day Zimbabwe), for example, in August 1967 two Alouette IIIs, operating from Katimo Mulilo in the northeast of SWA, supported ground forces in Rhodesia. Alouette IIIs and Cessna 185s later supported SAP units in Rhodesia. The SAAF personnel were eventually withdrawn on 17 August $1976 .{ }^{46}$

In the late 1960s, the SAAF acquired nine Transall C-160Z transport planes from France (1969), ${ }^{47}$ as well as French helicopters: 17 large Sud Aviation SA321L Super Frelons (July 1967-November 1969) ${ }^{48}$ and 89 medium-sized Aerospatiale SA330C Pumas (1970-1975). ${ }^{49}$ Twenty Piaggio P-166S Albatross MPAs were bought from Italy (1968-1969)..$^{50}$ Later, the SAAF acquired its new front-line jets from France: 32 Mirage F1AZ fighter-bomber/ground-attack aircraft (1975-1976) and 16 Mirage F1CZ all-weather fighters (from 4 April 1975 onwards). ${ }^{51}$ These were the 
last offensive military aircraft to be procured overseas by the SAAF for more than 30 years, because the RSA's domestic policy of apartheid led to gradual and later dramatic isolation, including the imposition of a mandatory UN arms embargo on 4 November $1977 .^{52}$

The NP government took action in order to counteract the potential effects of the military isolation, by revitalising South Africa's arms industry in the 1960s. On 3 June 1966, the first Impala MB-326M jet training aircraft (designed and built in Italy) was handed over to the SAAF, and in the following year, the first locally built Impala Mk I made its maiden flight. Up to 29 August 1974, the SAAF accepted a total of 151 MB-326 Mk Is. ${ }^{53}$ Some of these aircraft became part of the Silver Falcons, i.e. the SAAF's display team. ${ }^{54}$ They were followed by an Italian-designed but locally licence-built advanced jet trainer, namely the MB-326KC Impala Mk II, of which the SAAF received 100 (22 April 1974-1982). These aircraft were used for training the SAAF's excellent pilots, photo reconnaissance and (in the case of the Mk IIs) for ground-attacks in the north of SWA and in Angola, in support of the SA Army. ${ }^{55}$ The SAAF also acquired 40 Aeritalia/Aermacchi AM-3CM Bosbok liaison/spotter aircraft (1972-1975), most of which had been built by the Atlas Aircraft Corporation in South Africa, and 40 Atlas C-4M Kudu light transport aircraft. ${ }^{56}$ Today (2012), examples of all these aircraft types can be seen at the SAAF Museum at AFB Swartkop, as well as at several other museums and locations in South Africa.

In 1973, a few women joined the SAAF, and during the next year, three air hostesses were appointed. By then there were some 200 female permanent force SAAF members. ${ }^{57}$

During the SADF invasion of Angola in 1975-1976 (Operation Savannah), the SAAF provided indispensable air support to the ground forces. Jets ensured SADF air superiority (with no interference by Angolan aircraft) and provided photo reconnaissance. ${ }^{58}$ Transport aircraft provided troop and stores replenishment, ${ }^{59}$ while helicopters and light aircraft supported the SA Army in various ways. ${ }^{60}$ When 24 SADF personnel, as well as two civilians, had to be picked up behind enemy lines at Ambrizete (28 November 1975), a Wasp helicopter operating from the frigate SAS 
President Steyn proved its worth. ${ }^{61}$ Throughout the war "up north on the border", SAAF helicopters continued to play a very important role. ${ }^{62}$

Operation Reindeer (May 1978) would not have been successful without the support of the SAAF. Four of its C-130 and two C-160 transport planes flew in the 370 paratroopers who were used in storming the Swapo base at Cassinga, after five Buccaneers and four Canberras had softened up the target. After they had destroyed the base, the parabats were airlifted back to SWA by means of five Super Frelon and 15 Puma helicopters, while Buccaneers and Mirage IIICs kept an approaching enemy armoured column at bay, and a Bosbok liaison aircraft was used for communication purposes during the operation. ${ }^{63}$

In 1979, the SAAF continued to supply air support to the RSA's ground forces, for example, during Operation Rekstok and Operation Saffraan. In that same year, Mirage IIIEZ, Mirage IIID2Z, Impala Mk II, Kudu and Bosbok aircraft were deployed operationally for the first time. ${ }^{64}$ During Operation Protea (August-September 1981), the SAAF played a crucial role, flying 1112 sorties from Grootfontein and Ondangwa. Activities conducted during these sorties included knocking out enemy radar and other air defence systems. This was the first time that the SAAF encountered sophisticated air defence systems such as the SA-2 surface-toair missile systems, and a Mirage IIICZ was hit by an SA-7 missile, but landed safely. The SAAF also lost an Alouette III helicopter. ${ }^{65}$ On 6 November 1981, the SAAF scored its first operational "kill" since the Korean War, when two Mirage F-1CZs intercepted and shot down an Angolan MiG-21 jet above Cahama in south-east Angola. On 5 October 1982, another MiG-21 was downed in a dogfight with two Mirage F-1CZs. ${ }^{66}$

However, 1982 was not a good year for the SAAF. On 5 January, a Puma helicopter was shot down and three SAAF personnel were killed, and on 9 August, another Puma was shot down and the three aircrew plus 12 paratroopers died. Earlier that year (1 June), an Impala Mk II was shot down near Cuvelai and the pilot was killed. On 10 July, a Bosbok crashed and the two-man aircrew died, and on 14 July, a Merlin IVA VIP passenger plane of the SAAF and a civilian plane collided near Pretoria - five SAAF personnel (including two major generals) and three civil servants in the SAAF plane, as well as the pilot and four passengers (including two 
children) in the civilian plane, died. ${ }^{67}$ On 20 May 1983, uMkhonto weSizwe (MK), the armed wing of the African National Congress (ANC), detonated a bomb in front of the SAAF Headquarters in downtown Pretoria - at least 16 people (including three SAAF personnel) died and approximately 200 were injured. The SAAF hit back by striking ANC bases in Maputo, Mozambique. ${ }^{68}$

During Operations Moduler and Hooper against Swapo and Fapla forces in Southern Angola (1987-1988), Mirage F-1AZs flew 683 sorties and dropped more than 3000 bombs on enemy targets, while Buccaneers carried out 99 sorties, dropping approximately 700 bombs. One Mirage F$1 \mathrm{AZ}$ and one Bosbok were shot down. ${ }^{69}$ SAAF aircraft, and especially helicopters, continued to perform many successful casualty evacuation ("casevac") operations, thereby saving the lives of many soldiers. ${ }^{70}$

During the course of the war, as in previous years, the SAAF was called upon from time to time to perform work of a humanitarian nature, for example, providing food as well as relief equipment to flood victims in the RSA, SWA and Lesotho in $1987 .^{71}$ When a Boeing 747 Combi of the South African Airways crashed near Mauritius (28 November 1987), killing all 159 passengers and crew on board, the SAAF loaded two of its Puma helicopters into C-160 transport aircraft and flew them to Mauritius to assist in finding and recovering wreckage and bodies. ${ }^{72}$ Several other humanitarian and similar kinds of relief operations were conducted, including the provision of food, blankets, medicine and other relief aid to Lesotho in July 1988, when heavy snowfalls cut off thousands of people from the outside world. ${ }^{73}$ SAAF aircraft and helicopters also continued to patrol the RSA's coastal waters, rescuing the crews of stricken ships. ${ }^{74}$ In 1987, the range of the SAAF's jet aircraft was extended with the acquisition of five Boeing 707-320C in-flight refuelling aircraft - large jets that could also be used for electronic warfare, command and control, communications, search and rescue, and as transport for personnel and/or stores. ${ }^{75}$

During the war years, 1966-1989, the SAAF fought on its own as an air force for the first time. This was also the first time that it had taken part in an unconventional war, albeit that in the course of the 1980s, the war "up north" gradually acquired a more conventional dimension. Almost all SAAF aircraft and helicopter types were deployed "on the border" at some 
stage. All things considered, the SAAF was very successful in this conflict, albeit that during the last few years of the war "up north", the South African forces had to deal with contested (some would say a lack of) air superiority in south-east Angola, which had a definite effect on the way in which the South Africans conducted their operations, for example, in the area of the Lomba River. Nonetheless, together with the other arms of the SADF, the SAAF created opportunities for politicians to hammer out a diplomatic solution for the conflict. ${ }^{76}$ Total SAAF losses during the "war years up north" amounted to one Mirage F-1AZ, one Mirage IIIR2Z, one Canberra, five Impala Mk IIs, one Bosbok, one Cessna 185, four Pumas, five Alouette IIIs and three unmanned remotely piloted vehicles (all as a result of direct enemy action), while the following aircraft were also lost in the operational area: one Mirage F-1AZ, three Impala Mk IIs, one Kudu, one Cessna 185, three Pumas and three Alouette IIIs. ${ }^{77}$

In the meantime, the Mirage III fleet was upgraded by the Atlas Aircraft Corporation. The first Cheetah, as the refurbished aircraft were called, was shown to the public on 16 July 1986. By June 1995, 38 Cheetah C single-seater fighters had been delivered to the SAAF. Other conversions included the six Cheetah Ds (two-seater multi-role trainers/fighters, an upgrade of the Mirage IIIDZ and IIID2Z) and (from 1988 onwards) 16 Cheetah Es (single-seater multi-role, all-weather fighters). ${ }^{78}$ (Examples of the Cheetah C, D and E aircraft can be seen at AFB Swartkop.) Other developments included the unveiling of the new Darter V32C air-to-air missile (later followed by other versions) and the Seeker unmanned aerial vehicle. $^{79}$ And from the late 1980s, the Puma helicopters were modified and henceforth known as the Oryx. ${ }^{80}$ Back on the "home front", dramatical political changes would soon take place, and these changes would, in due course, lead to further challenges for the SAAF.

\section{A New Air Force for a New South Africa, 1990-2012}

In the wake of the end of the Namibian War of Independence, the SAAF was drastically downsized. In 1989, the SAAF had 11000 personnel, 317 combat aircraft (43 Mirage F-1s, 50 Cheetahs/Mirage IIIs, five Buccaneers, seven Canberras, 92 Impala Mk IIs and 120 Impala Mk Is), 130 T-6G Harvards, 34 AM-3C Bosbokke, 20+ C-4M Kudus, 20 Cessna 185s, 19 Albatrosses, four Boeing 707-320s, seven C-130Bs, nine C-160s, seven DC- 
4 Skymasters, 39 C-47 Dakotas, four HS-125-400Bs, two Falcon 50s, one Cessna Citation II, one Viscount, eight Wasp helicopters, 95 Puma/Oryx helicopters, 14 Super Frelon helicopters and 70 Alouette III helicopters. ${ }^{81}$

Thus, in 1989, the SAAF had at least 801 aircraft and helicopters of 24 types. The corresponding figures for its inventory in April 1994 (when the SAAF became part of the new South African National Defence Force (SANDF) and the RSA's first-ever truly democratic elections were held) were as follows: approximately 10000 personnel (still almost exclusively all white, including some 3000 national servicemen and 400 women), with 29 Mirage F-1AZs, 30 Cheetahs, 75 Impala Mk IIs, 115 Impala Mk Is, 130 T-6G Harvards, 26 Cessna 185s, four Boeing 707-320s, seven C-130Bs, one C-235M, 39 C-47 Dakotas, four C-212s, one Falcon 900A, three HS-125400Bs, two Falcon 50s, two Super King Air 200s, two Cessna Citation IIs, three BN-2s, 12 Cessna 208 Caravans, one IAI-1124, two Skyvans, one Cessna 152, 63 Oryx helicopters, 63 Alouette III helicopters, ten BK-117 helicopters and one SA-365N1 helicopter. ${ }^{82}$ So, in 1994, the SAAF had 636 aircraft and helicopters of 26 types. Since 1989, several squadrons had been disbanded, a number of bases and units had been closed down, and all the remaining Buccaneer (five), Canberra (six sold to Peru), ${ }^{83}$ Transall C-160 (nine), DC-4 Skymaster (seven), Bosbok, Kudu and Albatross aircraft, as well as the remaining Super Frelon and Wasp helicopters, had been withdrawn from service. Several of these aircraft and helicopters found their way to SAAF museums.

But there were also positive developments, for example, the prototype Rooivalk XH-2 attack helicopter was unveiled on 15 January 1990. In the course of the 1980s, the SADF identified the need to acquire attack helicopters. The result was the indigenously designed and built Rooivalk, of which the first prototype was flown in 1990. Although there was initially a need to acquire 36 such helicopters, only 12 were built, and the first ones were officially handed over to the SAAF on 17 November $1998 .{ }^{84}$ In the meantime, some of the SAAF's Dakotas were rebuilt. The first (of 38) "new" turbine-powered Douglas C-47TP Turbo Dakota was rolled out in August $1991 .^{85}$ From November 1994 onwards, the SAAF introduced into service the first of 60 new Swiss-manufactured Pilatus PC-7 MkII Astra basic trainers to replace the venerable Harvards. ${ }^{86}$ The political changes of 1994 however also meant that the SANDF, including the SAAF, had to be 
"transformed", which - as had occurred in the wake of the political changes of 1948, and during the following years - led to "cultural changes" in the SAAF, for example, the new government wanted the SANDF, and consequently also the SAAF, to be more representative of all the country's cultural groups, and the dominant white/Afrikaner culture had to be replaced by a more inclusive "African" culture.

The most dramatic single rescue mission in the history of the SAAF occurred on 4 August 1991, when 219 passengers of the passenger ship Oceanos, which sank in heavy seas off the Transkei coast, were rescued. (Some 300 other passengers escaped by using the ship's lifeboats - not a single life was lost.) Three Dakota MPAs, a C-130 and a C-160 were immediately dispatched to the scene of the disaster, followed later by a Cessna 208 Caravan, and in due course, the above-mentioned 219 passengers were lifted off the stricken ship by 11 Puma helicopters, supported by two Alouette IIIs. ${ }^{87}$

The SAAF was also involved in many other search-and-rescue missions. In December, two C-130s flew on patrol all the way to Marion Island (a South African possession in the remote southern Indian Ocean), and the SAAF also took part in several peace-time exercises. Humanitarian missions were not restricted to South African territory: when Somalian war refugees in Kenya faced starvation, two SAAF C-130s were sent (in September 1992) with emergency supplies. ${ }^{88}$ And in the course of the 1990s, the SAAF assisted the victims of floods in Mozambique on several occasions, saving the lives of tens of thousands of people in the process. ${ }^{89}$

After the so-called independent TBVC countries, i.e. Transkei, Bophuthatswana, Venda and Ciskei, were re-incorporated into the RSA, the SAAF took over the air wings of these countries, which meant the acquisition of, for example, a single CASA/Airtech CN.235 transport plane, three CASA C.212-200s, two CASA C.202-300s, two Britten-Norman BN2A Islanders, a single Beechcraft King Air 200, a single Beechcraft King Air 300, a single Pilatus PC-6 Turbo Porter, three Pilatus PC-7 trainers, nine Eurocopter BK117 light helicopters and one Eurocopter AS365 Dauphin. ${ }^{90}$

Other acquisitions (purchased directly by the SAAF) were 12 Cessna 208 Caravan light passenger aircraft (from June 1988 onwards, replacing the 
Kudus, and used for reconnaissance, casualty evacuation, paratrooping, and airborne command and control), ${ }^{91}$ a single Dassault Falcon 900A (acquired in 1991; used as transport for the RSA's State President and senior Cabinet ministers on foreign visits), two Dassault Falcon 50s (acquired in the early 1980s for VIP flights), and two Cessna Citation IIs (acquired in 1982 and 1994 for VIP flights and casualty evacuation). ${ }^{92}$

While a few new aircraft and helicopters were acquired, many others were withdrawn from service. The Mirage F-1s, which had played such an important role in the war "up north", were withdrawn from service on 25 November 1997 when 1 Squadron closed down, ${ }^{93}$ while the remaining two Boeing 707-320C in-flight refuelling aircraft were decommissioned on 2 November 2007. ${ }^{94}$ At AFB Swartkop, the SAAF Museum displays a Mirage F-1CZ (serial number 203, i.e. one of the aircraft that shot down a MiG-21 over Angola) and a Boeing 707-320C (number 1419).

With the SAAF facing block obsolescence with regard to certain aircraft and helicopter types, the arms deal that was announced on 19 November 1998 was an expensive but necessary life-buoy for the SAAF (and the SA Navy). It was announced that from 2005 to 2012, the SAAF would acquire 28 (later reduced to 26) Gripen jets (including nine two-seater trainers), 24 Hawk advanced trainers, 30 Agusta A-109 light utility helicopters and four Super Lynx anti-submarine warfare helicopters. ${ }^{95}$ (The SAAF's remaining Cheetah jets were withdrawn from service on 2 April $2008 .{ }^{96}$ ) With all the new aircraft and helicopters now in service, the SAAF has a fair number of modern and sophisticated aircraft and helicopters in its inventory, albeit that the old aircraft and helicopters were not replaced on a one-to-one basis, leaving the SAAF, relatively speaking, in a weaker position. In the meantime, on 22 October 2002, a new Boeing 737-800 Presidential VIP aircraft arrived. ${ }^{97}$

While these developments took place, the SAAF continued to take part in many humanitarian relief operations (for example in flood-ravaged Mozambique, to which reference has already been made). It also supported the SA Army in peace-keeping operations in Africa, for example in Burundi, the Democratic Republic of the Congo (DRC) and in the Sudan, and assisted the people of South Africa, as well as people in other African countries, in many other ways, for example, by rendering assistance in the DRC during 
the November 2011 election in that country. ${ }^{98}$ It is thus unfortunate that the order for eight new large Airbus A400M transport aircraft had to be cancelled (in November 2009) owing to escalating costs. ${ }^{99}$ Hopefully, the SAAF will still acquire new transport aircraft - sooner rather than later.

\section{Concluding Perspectives}

Since the UDF was established in 1912, and in particular since 1920, when the SAAF was established, South African airmen (and later also women) have rendered excellent service to the other arms of South Africa's defence force. From the sources referred to in this article, it is clear that most of these sources are of a more popular nature, often written or compiled by socalled amateur historians, motivated by a passion for aviation history. From a professional and academic military history point of view, there are indeed still many aspects of the SAAF's history that could be explored.

Since it was established in 1920, the SAAF has had more than 8000 aircraft and helicopters in service. ${ }^{100}$ Of these, more than 300 of those that have been withdrawn from service have been preserved in SAAF museums, other museums, by private companies or individuals, or as gate guards. According to the authoritative The Military Balance 2012, the SAAF's inventory today (2012) consists of 17 Gripen C single-seat multi-role jets and nine Gripen D twin-seater trainers, 24 Hawk Mk120 advanced jet trainers, 50 Pilatus PC-7 Mk II Astra basic trainers, eight Lockheed C130B/BZ Hercules transport aircraft, three Beech 200C King Airs, one Beech 300 King Air, ten C-47TP Turbodaks (three for transport, five for maritime patrol and two for electronic warfare), two CASA C-212-200 Aviocars, two CASA C-212-300 Aviocars, ten Cessna 185s, 11 Cessna 208 Caravans, two Cessna 550 Citation IIs, one CASA CN-235, one Pilatus PC12, one Boeing B-737, one Falcon 900, two Falcon 50s, 11 Rooivalk attack helicopters, four Super Lynx 300s, 39 Oryx helicopters, 29 Agusta A-109 light helicopters and eight BK-117 helicopters. Compare the SAAF's 10653 personnel and 50 combat aircraft with the air forces of Brazil (69 480 personnel and 235 combat aircraft), India (127 200 and 798), Russia (167 000 and 1793), the People's Republic of China (at least 300000 and 1 693), and the USA (334 568 and 2 137). ${ }^{101}$ 
Ideally, the SAAF should have, inter alia, 48 front-line jet aircraft, 36 jet trainers, four large transport aircraft (for example, A400Ms), 12 C-130s, 20 smaller transports (for example C27s or C295s), five MPA, three inflight refuelling aircraft, 24 attack helicopters, eight anti-submarine warfare helicopters, and 50 Oryx and 50 A-109 helicopters. This will enable the SAAF to play a more meaningful role in, for example, peacekeeping operations, humanitarian relief operations, and anti-piracy patrol work.

As was often the case in the past, a lack of money and trained personnel continues to plague the SAAF. In the years 2001-2009, for example, 298 pilots and 1684 technicians resigned from the SAAF, and by 2008, there were apparently only 20 fighter pilots left. By November 2009, only 52 out of 122 engineer posts, 763 out of 1630 technical posts, and 237 out of 369 pilot posts were filled. ${ }^{102}$

In the course of its history, the SAAF has faced (and overcome) many problems, and - notwithstanding its present-day challenges - it has, in the past decade, acquired a relatively large number of new aircraft and helicopters. Consequently, it is still a force to be reckoned with. The SAAF played a significant role in the Second World War, made a small but not insignificant contribution during the war in Korea, and played a major role in the war in Namibia and in Angola. The SAAF's pilots have ranked as among the best-trained pilots in the world, and have proved their ability above any doubt. Unfortunately, politics also tainted the SAAF's reputation. After many years of being associated with the apartheid war machine, the SAAF has, since 1994, developed into a force associated with peace-keeping and humanitarian relief, and it is hoped that the SAAF's personnel will build on its history and traditions, which go back all the way to 1920. Consequently, it is of the utmost importance that the SAAF's museums be retained, and those aircraft and helicopters that have been preserved, must be cared for - as part of all South Africans' military, aviation and cultural heritage.

H Potgieter \& W Steenkamp. Aircraft of South African Air Force. Cape Town: Struik, 1981, 16-18; JA Brown. South African forces in World War II 2: A gathering of eagles: The campaigns of the South African Air Force in Italian East Africa June 1940 - November 1941 with an introduction 1912-1939. Cape 
Town: Purnell, 1970, 1-3; CJ Nöthling. Geskiedenis van die Suid-Afrikaanse Weermag 1. Silverton: SAMHIK, 1995, 19-20, 33-34.

Potgieter \& Steenkamp op. cit., p. 18; Nöthling op. cit., pp. 34-35; Dictionary of South African Biography (DSAB) I. Cape Town: Nasionale Boekhandel, 1968, 661-662.

Potgieter \& Steenkamp op. cit., p. 18. For the history of this historic base, see D Becker. The eagles of Zwartkop. Nelspruit: Freeworld Publications, 1996.

Potgieter \& Steenkamp op. cit., pp. 19-20; Brown op. cit., pp. 10-12; AG Oberholster. Die Mynwerkerstaking: Witwatersrand, 1922. Pretoria: Raad vir Geesteswetenskaplike Navorsing, 1982, passim; Nöthling op. cit., pp. 40-41. Potgieter \& Steenkamp op. cit., pp. 20-21; Brown op. cit., pp. 19-20. MN Louw \& JS Bouwer. The South African Air Force at war: A pictorial history. $2^{\text {nd }}$ ed. Melville: Publisher, 1995, ix.

Potgieter \& Steenkamp op. cit., p. 21; Brown op. cit., p. 23.

$\mathrm{G}$ de Vries. Wingfield: A pictorial history. S.l.: S.a.

Potgieter \& Steenkamp op. cit., pp. 9, 21-22.

10 Brown op. cit., pp. 289-306; Potgieter \& Steenkamp op. cit., pp. 22-23; I Spring. Flying boat: The history of 262 Squadron RAF and the origins of 35 Squadron SAAF. Johannesburg: Spring Air, 1995, 22-122.

11 G Ellis. Serve to save - servimus ut servemus: The South African Air Force at sea. Nelspruit: Freeworld, 2001, 9-106; A du Toit. South Africa's fighting ships: Past and present. Rivonia: Ashanti, 1992, 250-251, 255.

12 Brown op. cit., pp. 30-286; Potgieter \& Steenkamp op. cit., pp. 24-25, 145, 151; Louw \& Bouwer op. cit., pp. 1-13; M Schoeman. Springbok fighter victory: SAAF fighter operations 1939-1945 1: East Africa 1940-1941. Nelspruit: Freeworld, 2002, passim.

13 JA Brown. South African forces in World War II 4: Eagles strike: The campaign of the South African Air Force in Egypt, Cyrenaica, Libya, Tunisia, Tripolitania and Madagascar 1941-1943. Cape Town: Purnell, 1974, 1-382; GHJ Martin \& ND Orpen. South African forces in World War II 6: Eagles victorious: The operations of the South African forces over the Mediterranean and Europe, in Italy, the Balkans, and the Aegean, and from Gibraltar and West Africa. Cape Town: Purnell, 1977, 1-12; Potgieter \& Steenkamp op. cit., pp. 25-28, 36-37, 39, 153, 155, 166; Louw \& Bouwer op. cit., pp. 14-50; M Schoeman. Springbok fighter victory: SAAF fighter operations 1939-1945 2: Victory over North Africa. Nelspruit: Freeworld, s.a., passim.

14 Brown, Eagles strike op. cit., pp. 383-400; JA Clayton. "The South African Air Force in the Madagascar Campaign”. Military History Journal 9/2. 1992. 37-43.

15 Martin \& Orpen op. cit., pp. 13-52, 74-107, 121-134, 148-168, 212-228, 263307, 352-415, 428-445; Potgieter \& Steenkamp op. cit., pp. 29-33, 66, 68, 72, 75, 155; Louw \& Bouwer op. cit., pp. 56-66, 71-82. Martin \& Orpen op. cit., pp. 135-147, 178-201, 320-326; Potgieter \& Steenkamp op. cit., p. 133.

See, for example, Potgieter \& Steenkamp op. cit., p. 33.

Martin \& Orpen op. cit., pp. 169-177, 308-319, 333-334, 347-352, 416-418. PL Möller. 31 Eskader en 34 Eskader Suid-Afrikaanse Lugmag se aandeel aan die Warskou-operasies gedurende Augustus en September 1944. MA thesis. 
Stellenbosch University, 1985, passim; Martin \& Orpen op. cit., pp. 246-262; L Isemonger. The men who went to Warsaw. Nelspruit: Freeworld, 2002, passim.

See, for example, Louw \& Bouwer op. cit., p. 97; Potgieter \& Steenkamp op. cit., pp. 9, 33.

P Bagshawe. Warriors of the sky: Springbok air heroes in combat. Johannesburg: Ashanti, 1990, 1-18, 25-62, 70-90, 97-154, 162-244, 259-266; DSAB 4. Durban: Butterworth, 1981, 338-339, 407-408, 635-636; ECR Baker. Ace of aces: $M$ St $J$ Pattle - Top scoring allied fighter pilot of WW II. Rivonia: Ashanti, 1992, passim.

Potgieter \& Steenkamp op. cit., pp. 80-81, 84, 171; H Potgieter \& L Birns. More than game: A salute to the South African Air Force. Morningside: AirReport, s.a., 58-63; Spring op. cit., pp. 135-138. The Dakota is one of the most remarkable aircraft ever designed and built. More than 10000 were built in the USA, as well as many others in the Soviet Union and in Japan. See in general JMG Gradidge, in collaboration with JM Davis \& JA Whittle. The Douglas DC-3 and its predecessors. Tonbridge: Air-Briton, 1984. Several Dakotas have been preserved in South Africa. Unfortunately, no Sunderlands have survived in South Africa, but Sunderlands are preserved in the United Kingdom at the RAF Museum at Hendon, London, and also in Southampton.

Potgieter \& Steenkamp op. cit., pp. 164-165, 178.

CJ Nöthling. Geskiedenis van die Suid-Afrikaanse Weermag 2. Silverton: SAMHIK, 1996, 9-10; Potgieter \& Steenkamp op. cit., p. 34. One of these helicopters can be seen at the SAAF Museum at AFB Swartkop. Both the other two SAAF S-51s crashed (in 1951 and 1952 respectively) and were written off. Brent op. cit., p. 323.

See, for example, Potgieter \& Steenkamp op. cit., p. 34.

See, for example, Louw \& Bouwer op. cit., pp. 119-139; Potgieter \& Steenkamp op. cit., pp. 9-10, 34, 47; W Brent, “Flying Cheetahs”: Korea 19501953. Nelspruit: Freeworld, s.a., 81; Brent op. cit., pp. 328-331. Over and above the five Sabres that crashed, another Sabre returned to base, but belly-landed.

Brent op. cit., pp. 179-196; Potgieter \& Steenkamp op. cit., pp. 138-139, 174175; Potgieter \& Birns op. cit., pp. 92-103. See, in general, D Becker \& W Brent. AT-6 Harvard in South African Service: A pictorial history. Nelspruit: Freeworld, 1995; PC Smith. North American T-6: SNJ, Harvard and Wirraway. Marlborough: Crowood, 2000; D Hagedorn. North American NA-16/AT-6/SNJ. North Branch, MN: Speciality Press, 1997.

Potgieter \& Steenkamp op. cit., pp. 156-157, 177.

Ibid., pp. 58-59. The last 17 were withdrawn from service in 1980.

Ibid., pp. 102-103. After the last seven were withdrawn from service in 1984, one was preserved at AFB Ysterplaat (No. 1722), near Cape Town, while another (No. 1721) can be seen at AFB Swartkop. The last flying ex-SAAF Shackleton (No. 1716) crashed in the Sahara Desert on 13 July 1994, en route to an air show in the United Kingdom.

Potgieter \& Birns op. cit., p. 112.

Potgieter \& Steenkamp op. cit., p. 151; Brent op. cit., pp. 320-321. 
33 H-R Heitman. South African arms \& armour: A concise guide to armaments of the South African Army, Navy and Air Force. Cape Town: Struik, 1988, 150152. Potgieter \& Steenkamp op. cit., pp. 44-45, 168-169; Veg 3. S.a., 28-31, 34-35. A Mirage IIIRZ can be seen at the SAAF Museum at AFB Ysterplaat, while several Mirages are preserved at AFB Swartkop. Potgieter \& Steenkamp op. cit., pp. 64-65; M Hamence \& W Brent. Canberra in Southern African Service. Nelspruit: Freeworld, 1998, 58-96.

35 Potgieter \& Steenkamp op. cit., pp. 52-53.

$36 \quad$ Potgieter \& Steenkamp op. cit., pp. 90-91; Veg 7. S.a., 28-31, 34-35; Potgieter \& Birns op. cit., pp. 52-57. In 1997 to 1998, the SAAF acquired five additional C-130s from the USA. The South African airfreight company, SAFAIR, at one stage operated 16 Lockhead L-100 variants, assisting the SADF in flying personnel and cargo to and from SWA/Namibia during the war 'up north'. Potgieter \& Birns op. cit., pp. 78-81; Potgieter \& Steenkamp op. cit., pp. 150151.

38 Potgieter \& Steenkamp op. cit., pp. 118-119, 173-174; Potgieter \& Birns op. cit., pp. 103-113. For the personal reminiscences of an SAAF helicopter pilot, see M Wilkens. Chopper pilot: The adventures and experiences of Monster Wilkens. Nelspruit: Freeworld, 2000.

Potgieter \& Steenkamp op. cit., pp. 112-113, 173. The last nine Wasps were withdrawn from service in 1990. Of these, one can be seen at the SA Navy Museum in Simon's Town (No. 85) and two at AFB Swartkop (No. 90 and 96). Potgieter \& Steenkamp op. cit., pp. 152-153. The Viscount was sold to a Zairean operator in 1991. Potgieter \& Birns op. cit., p. 15.

$41 \quad$ Potgieter \& Steenkamp op. cit., pp. 86-87, 171. The last seven were withdrawn from service in January 1993. One is to be seen at the SAAF Museum at AFB Swartkop.

42 Nöthling, 2 op. cit., p. 11. For post-war radar developments in South Africa, see T Cockbain. Sweeping circles in the sky. Nelspruit: Freeworld, 2003.

43 For more on the Namibian War of Independence, see, for example, W Steenkamp. South Africa's Border War 1966-1989. Gibraltar: Ashanti, 1989; FJ du T Spies. Operasie Savannah: Angola 1975-1976. Pretoria: SA Weermag Direktoraat Openbare Betrekkinge, 1989.

Brent op. cit., p. 252 et seq.; The Military Balance 1965-1966. London: The International Institute for Strategic Studies, 1965, 36.

45 For the SAAF's role in the war 'up north', see D Lord. From fledgling to eagle: The South African Air Force during the Border War. Johannesburg: 30 Degrees South, 2008. Earlier, Leo Barnard (†2009) completed a comprehensive history of the SAAF, but the manuscript was unfortunately never published, although Barnard did publish several articles on the history of the SAAF in the Journal for Contemporary History 31/3. 2006 and 34/1. 2009.

46 L Barnard. "Die Suid-Afrikaanse Lugmag (SALM) se optrede in die teaters Angola en Rhodesië (circa 1966-1974) as aanloop tot die Grensoorlog”. Journal for Contemporary History 31/3. 2006. 74-90. See also N Jackson \& R van Malsen. The search for Puma 164: Operation Uric and the assault on Mapai. Johannesburg: 30 Degrees South, 2011. 
47 Potgieter \& Birns op. cit., pp. 66-71; Potgieter \& Steenkamp op. cit., pp. 96-97, 172. After all nine were withdrawn from service on 8 January 1993, one was preserved at the SAAF Museum at AFB Swartkop. Potgieter \& Steenkamp op. cit., pp. 132-133. After the remaining 14 were withdrawn from service in 1990, one was preserved at the SAAF Museum at AFB Swartkop; another at the SAAF Museum at AFB Ysterplaat. Potgieter \& Steenkamp op. cit., pp. 124-125.

50 Ibid., pp. 108-109. The last 19 were withdrawn from service in 1990 and 1991. One has been preserved on a pedestal outside the airport at Port Elizabeth. Others were sold. Of these, two crashed in the Mpumalanga Province on 14 August 2011, killing all 13 persons on board. Beeld. 22 September 2011. 9; The Star. 22 September 2011. 8; Daily News. 23 September 2011. 6.

51 Potgieter \& Steenkamp op. cit., p. 36; Veg 4. S.a., 28-31, 34-35; Potgieter \& Birns op. cit., pp. 34-41.

52 See, for example, A Wessels. "The United Nations arms embargo against South Africa, 1977-1994”. War \& Society 29/2. 2010. 137-153.

53 Potgieter \& Steenkamp op. cit., pp. 70-71, 170-171.

54 Potgieter \& Birns op. cit., pp. 192-199; W Brent (compiler). Silver Falcons. Nelspruit: Freeworld, 2007, 9-104.

55 Potgieter \& Birns op. cit., pp. 42--51; Potgieter \& Steenkamp op. cit., pp. 71, 170-171. The last Impala Mk Is and Mk IIs were withdrawn from service on 30 November 2005. Examples that have been preserved can be seen at the SAAF Museum at AFB Swartkop, as well as at several other places.

56 Potgieter \& Steenkamp op. cit., pp. 144-145. The remaining Kudus were withdrawn from service in 1990, and the remaining Bosbokke in the second half of 1992. Ad Astra 13/6. 1992. 16.

$57 \quad$ Nöthling, 2 op. cit., p. 22.

58 See, in general, RS Lord. "SAAF fighter involvement in the Border War, 19651988”. Journal for Contemporary History 31/3. 2006. 251-266.

59 See in general L Barnard. "The South African Air Force's transport aircraft: Acquisition and utilization during the Border War”. Journal for Contemporary History 31/3. 2006. 233-250.

60 See, for example, L Barnard. "Die Suid-Afrikaanse Lugmag se optrede tydens Operasie Savannah - relevant of 'n noodsaaklike ergernis?”. Journal for Contemporary History 31/3. 2003. 66-80.

61 Louw \& Bouwer op. cit., pp. 140-148; C Bennett. Three frigates: President Class frigates bring the SA Navy to maturity. Durban: Just Done Productions, 2006, 159-166; Steenkamp op. cit., pp. 51-52; Spies op. cit., pp. 141-142; Du Toit op. cit., pp. 231-232.

62 See, for example, AJ Venter. The Chopper Boys: Helicopter warfare in Africa. Halfway House: Southern Book, 1994, 127-168, 171-203.

63 See, for example, Louw \& Bouwer op. cit., pp. 149-152; L Barnard. "The Battle of Cassinga, 4 May 1978: A historical reassessment - Part 1: The course of the battle and ensuing controversy”. Journal for Contemporary History 31/3. 2006. 131-140; L Barnard. "Die Suid-Afrikaanse Lugmag se aandeel in die militêre optrede tydens die Suid-Afrikaanse Weermag se aanval op Cassinga, 4 Mei 1978”. Journal for Contemporary History 28/2. 2003. 81-93. 
64 Louw \& Bouwer op. cit., pp. 153-161; L Barnard. "The role of the South African Air Force (SAAF) during the SADF's cross-border operations in Angola, 1978-1981: A historical exploration”. Journal for Contemporary History 31/3. 2006. 267-282. RS Lord op. cit., pp. 261-262; Louw \& Bouwer op. cit., pp. 174-192.

D Lord. Vlamgat: The story of the Mirage F1 in the South African Air Force. Weltevreden Park: Covos-Day Books, 2000, 110-112, 128-131; Louw \& Bouwer op. cit., pp. 193, 202-203; Beeld. 7 December 1981. 15; Pretoria News. 7 December 1981. 23; The Natal Mercury. 6 October 1982. 1; Die Transvaler. 6 October 1982. 1.

Rand Daily Mail. 16 July 1982. 1; Beeld. 16 July 1982. 1-2; The Star. 15 July 1982. 1; Die Vaderland. 15 July 1982. 1; Pretoria News. 15 July 1982. 1; Louw \& Bouwer op. cit., pp. 194-201.

$68 \quad$ Beeld. 21 May 1983. 1.

69 Louw \& Bouwer op. cit., pp. 222-234; Lord, From fledgling to eagle op. cit., p. 498.

$70 \quad$ Steenkamp op. cit., pp. 244-245.

71 See, for example, D Lord. Standby! South African Air Force Search and Rescue. Johannesburg: 30 Degrees South, 2010.

72 See, for example, Finansies \& Tegniek. 18 December 1987. 9; Beeld. 21 July 2011. 9.

$73 \quad$ The Star. 16 July 1988. 1 and 26 July 1988. 2; The Cape Times. 20 July 1988. 1; Die Vaderland. 18 July 1988. 6.

$74 \quad$ See, for example, Die Burger. 11 July 1986. 1; Beeld. 25 July 1983. 2; The Cape Times. 29 December 1986. 1.

75 Potgieter \& Birns op. cit., pp. 28-33.

76 See, in general, L Barnard. "Enkele aantekeninge oor die militêre struktuur en proses van die Suid-Afrikaanse Lugmag (SALM) gedurende die Grensoorlog”. Journal for Contemporary History 31/3. 2003. 215-232; L Barnard. "Die SuidAfrikaanse Lugmag se finale onttrekking uit die teater van Suid-Angola en Noord-Namibië - die einde van 'n era"; L Barnard. "Cross-border operations of the SAAF in Angola: 1987-1989. Prelude to the final stages of the war" and L Scholtz. "The air war over Angola, 1987-1988: An analysis". Journal for Contemporary History 34/1. 2009. 196-206, 223-236, 237-265.

77 Lord, From fledgling to eagle op. cit., pp. 491-500. Three men died when their Cessna 185 was shot down near Ebo in Angola on 25 November 1975. Efforts to bring back their bodies, as well as that of another SADF soldier killed near Ebo, made headline news in 2012. The remains of the three who died on 25 November were eventually brought back to South Africa in June 2012.

78 Potgieter \& Birns op. cit., pp. 20-23, 27; W Brent. Cheetah: Guardians of the nation. Nelspruit: Freeworld, 2008, passim.

79 See, for example, African Armed Forces. 2007. 15.

$80 \quad$ Potgieter \& Birns op. cit., pp. 102-107.

81 The Military Balance 1989-1990. London: The International Institute for Strategic Studies, 1989, 139-140. 
The Military Balance 1993-1994. London: The International Institute for Strategic Studies, 1993, 218-219. See also Heitman op.cit., pp. 145-178; Potgieter \& Steenkamp op. cit., p. 36 et seq.

Hamence \& Brent op. cit., p. 95.

Beeld. 16 January 1990. 2; Business Day. 16 January 1990. 3; Die Transvaler. 15 January 1990. 1; The Citizen. 16 January 1990. 4; Potgieter \& Birns op. cit., pp. 132-135.

Potgieter \& Birns op. cit., p. 58; Brent, 85 years op. cit., pp. 252-257.

Beeld. 2 December 1994. 4; Die Burger. 29 November 1994. 11; Potgieter \& Birns op. cit., pp. 86-91. Some of these aircraft in due course became part of the SAAF's revitalised "Silver Falcons" display team. See Brent Silver Falcons op. cit., 105-141.

L Barnard. "Die Suid-Afrikaanse Lugmag se reddingspoging van die passasiers vanaf die luukse plesierboot Oceanos: 'n Menslike drama". Journal for Contemporary History 30/2. 2005. 163-179; The Star. 5 August 1991. 1; The Citizen. 24 October 1991. 5; Die Burger. 5 August 1991. 5; Venter op. cit., pp. 214-218.

The Cape Times. 7 September 1992. 7; The Star. 8 September 1992. 6; The Citizen. 7 September 1992. 4.

See, for example, The Citizen. 21 February 1996. 3 and 15 February 1997. 4; Nöthling, 2 op. cit., p. 54; The Star. 25 February 1997. 7; Eastern Province Herald. 22 August 1998. 3; The Star. 10 March 1999. 1 and 17 March 1999. 4; Pretoria News. 11 March 1999. 3. See, in general, D Lord. Fire, flood and ice: Search and rescue missions of the South African Air Force. Roodepoort: Covos Books, 1998.

Potgieter \& Birns op. cit., pp. 13, 64-65, 76-77, 82-85, 114-119; Brent 85 years op. cit., pp. 387-390, 392.

Potgieter \& Birns op. cit., pp. 72-75.

Ibid., pp. 120-123.

For a history of these aircraft in SAAF service, see Lord, Vlamgat op. cit. Six ex-SAAF Mirage F-1AZs were sold to Gabon, 2007-2008. The Military Balance 2012. London: The International Institute for Strategic Studies, 2012, 436.

African Pilot 7/1. 2008. 24-26; South African Soldier 15/3. 2008. 24-25.

Beeld. 19 November 1998. 1; Die Volksblad. 19 November 1998. 1; Armscor's Annual Report 2007. Pretoria: Armscor, 2007, 15. For the controversy with regard to the arms deal (allegations of corruption; high costs), see, for example, A Feinstein. After the party: A personal and political journey inside the ANC. Johannesburg: Jonathan Ball, 2007; T Crawford-Browne. Eye on the money: One man's crusade against corruption. Cape Town: Umuzi, 2007; P Holden. The arms deal in your pocket. Johannesburg: Jonathan Ball, 2008.

African Pilot 7/5. 2008. 28-33. Ten ex-SAAF Cheetah Cs and two Cheetah Ds were sold to Ecuador in December 2010, but only one C and the two Ds were delivered. The Military Balance 2012 op. cit., pp. 388, 409.

See, for example, The Star. 23 October 2002. 3; Pretoria News. 22 October 2002. 1; Beeld. 22 October 2002. 2.

Volksblad. 24 November 2011. 11. 
Business Day. 6 November 2009. 1; The Star. 6 November 2009. 3; Die Burger. 6 November 2009. 2.

Brent, 85 years op. cit., passim.

101 The Military Balance 2012, op. cit., pp. 62-64, 196-197, 237-238, 246, 378, 453. See also <www.saairforce.co.za> Accessed on 31 July 2012.

102 Business Day. 27 November 2009. 3; The Mercury. 14 September 2009. 3; Volksblad. 21 August 2009. 8 and 12 September 2009. 11. Statistics may vary, depending on the day on which the headcount is made. 